\title{
The game as an educative pretext: educate and educate oneself in a health formation program
}

\section{Cleidilene Ramos Magalhães}

Pedagogue; Doctor in Education; teacher, Department of Collective Health, Fundação Faculdade Federal de Ciências Médicas de Porto Alegre [Federal School of Medical Sciences Foundation of Porto Alegre], Porto Alegre, RS. cleidirm@fffcmpa.edu.br

\begin{abstract}
This article is focused on a game-based educative experience, developed with students of the $1^{\text {st }}$ year of the Medicine program of a federal public educational institution. The game was used as a privileged strategy to approach the students' communication, spontaneity and sensitiveness in the health education process. Through this game, it was possible to approach the theme "the students' mental health", where they could express their feelings as freshman students in the Medicine program. Such experience triggered learning opportunities for students and teachers, what, from Freire's perspective, is seen as a dialogic process of mutual formation with students. Its development favored the rethinking about the teaching practice in health, as well as subsidized the reorientation of the process of preventing and promoting mental health by means of proposals and supporting programs to students enrolled at the institution.
\end{abstract}

Key-words: Medical Education. Games and toys. Medicine Faculty.

\section{The origin of pretext}

This text aims at reporting an educative experience developed with health undergraduate students of the Medicine Program, for the Subject called Health Education and Communication, ${ }^{1}$ which has as one of its purposes to give students the opportunity of instructions and reflections on the student as an active subject in his/her teaching-learning process, as well as to facilitate experiences and reflections on the health education and communication process, and on the health professional's educative role both in terms of individual and collective action during graduation and in the future exercise of profession.

The experience involved the use of game in the health education process, a very significant didactic strategy to work on the sensitiveness and emotions of the people concerned (Torres et al., 2003), as well as to make self-knowledge possible for individuals and groups. In the

\footnotetext{
${ }^{1}$ Elective subject offered to students of the Medicine, Biomedicine and Nutrition programs, at the Federal School of Medical Sciences Foundation of Porto Alegre - FFFCMPA.
} 
experience reported, the game allowed the analysis of the health education theme, as well as the discussion and reflection by students of their own teaching process, what was developed in a double perspective: the contribution of the educative games to health professionals' formation and action and the experience of game within the group, focused on the students' mental health, students' and teachers' learning. A process of self-knowledge and reflection by students, and also of teachers' reflection and reorientation of the educative practice under consideration and other forming processes in which the teacher involved participates. The genesis of the educative process and the teacher's action itself carry the presupposition of inquiry, questioning, research and the constant reconstruction of such processes. Combined with that, the rethinking of the practice itself, as well as its record and analysis in a natural environment (Bogdan \& Biklen, 1994; Ludke \& André, 1986) allow teachers not only to document, but also use such records to subsidize their studies, their researches and reorient their own practice (Zabalza, 1994) as a teacher and a researcher. A process that is part, or rather, that should be part of the teachers' work, as one of the knowledge necessary for the conscious teachers' practice (Freire, 2000) and committed to the constant improvement of the teaching-learning process.

Thus, the work presented herein is featured as a reflective report of a teaching experience developed by the author. The data supporting this reflective analysis are the written records (written by students) of the game performed, as well as the observation in loco of the said game and its discussion with the participant students.

Then, we understand that the said report is directed by the qualitative perspective of research (Bogdan \& Biklen, 1994; Lüdke \& André, 1986), provided that it is based on data collected in a natural environment and involves an inquiring look (Freire, 2000) over the experience performed: the written records that came along it, the memories and reflections triggered at the moment of its performance, those distanced along time and those at the moment of producing this text.

In relation to that, it is worth mentioning that rethinking the teachers' practice itself and the rearrangement of educative activities and formation processes in development in the environment where they take place, characterize this experience and have in the last years been pointed as of primary importance when it comes to teachers' formation and performance (Barea et al.,2005; Mizukami et al., 2002, 1998; Schön, 1993).

We can even say that such process appears as a feasible and interesting possibility of searching more and more significant educative alternatives for students, due to its playful and educative nature and its commitment with the learning and formation of those professionals, who shall act essentially within the context of human interactions, who will deal with emotions, lives. Therefore, it's quite appropriate to provide them with a more humanized and sensitive formation on such concerns and the constant rethinking about this type of teachers' practice is more than convenient, it's necessary.

The text is structured as follows: it presents some notes about the professional graduation in health and procedures adopted by the institution, situating the subject's proposal under consideration; it raises the discussion about education in health and, particularly, the contributions made by playful activities, like the game, to the health professionals' humanistic formation; it presents the activity performed and its development for the group, for the subject direction and the direction of other subjects within the institution sphere. Finally, it introduces some reflections triggered by the experience based on health teachers' perspective, a process that involves teaching and being graduated in health in specific terms, and educating and being educated in health in more broad terms, from the social-educative standpoint.

\section{The professional formation in health: presuppositions and courses}

In the last years, especially from the early $90 \mathrm{~s}$, the debate about the formation of health professionals has been remarkable, not only for the proposals to reformulate the graduation programs, which respond for a professional profile that meets the social demands of population, but also for the primacy given to the search for improvement and humanization of such professionals formation (Lampert, 2002; Ramos-Cerqueira \& Lima, 2002; Garcia, 2001). Do such proposals mean a rescue or is this a scarcely explored approach in this formation area? 
What there is in mind is that this approach and the human dimension development in the health professional formation process are indispensable for its practice, in its relation with patients, in the performance of its educative role as a health professional and in social relations it establishes with people (teachers, its peers, other professionals, communities, etc.); and, therefore, they must be explored and experienced by students, undergraduate professionals.

Just like the student, Will the future professional develop attitudes and skills in a more humanized perspective if he/she does not experience them during its formation? If he/she is challenged, incited to show him/herself as a human person, endowed with feelings, emotions, wishes, expectations and needs; if he/she is confronted with others in his/her differences, so that he/she can take a lesson from them and learn how to comprehend, respect, value and live together, he/she will have unique opportunities to show him/herself as a more sensitive student and future professional able to perform more sensitive and humanized health practices.

Those proposals of change in the professional formation aim at surpassing the traditional formation model and seek essentially an entirety in heath practices, through an innovative educative process focused on the student and his/her learning process, with a bigger emphasis on health promotion, where the social reality and the health system is taken as the field of practice since the beginning of the formation process, just to name some of its presuppositions (Lampert, 2002).

It is worth emphasizing that such proposals find repercussion and reference, above all, in the experiences of popular education (whose precursor and basic theoretical reference is the educator Paulo Freire); in his interactions with the local social movements and his educative practices, essentially based on the dialog with the communities; in the popular knowledge and practices of health education that break with an authoritarian and normalizing formation and practices of biomedical, biologist health of the relations between health services and population (Vasconcelos, 2001). Ongoing proposals that really need to be fulfilled and built in the Brazilian schools' reality, but that move or try to move towards what Assis (2001) calls "a new sensitiveness in health practices". Practices focused on aspects very little valued up to this time within the contexts of formation and assistance practice in health: group dynamics, playful activities, educative games and groups, among others, that give room bringing up issues like health in the collective sphere, the sphere of exchanges and the possibility of deepening learning, strengthening bonds (Assis, 2001) and rescuing spontaneity, the playfulness and the human essence of each of us; aspects that must essentially taken into account and explored in the educative process developed with students, not for them (Freire, 2000).

These presuppositions and the authors that investigate and debate on education and human formation in a broader sense, as well as health education in a specific manner are our interlocutors in this reflective report. That's what we seek to express and elucidate below, in such a way that the experience can be better comprehended in terms of its theoretical foundation.

\section{Health education: Playful activities contributions and the dialogic educative process}

The educative experience dealt with by this text had its place during an elective subject that proposes to contribute to the health professionals formation in a humanistic perspective, directed to development of skills and attitudes like communication, the critical and creative thinking, and a responsible behavior before the educative role that those professionals have to perform within the social reality.

In a logical sense, the formation of those professionals within a humanistic perspective and, above all, the development of attitudes, like an ethic and responsible behavior, skills, like communication in the professional-patient relationship, and the critical and creative thinking do not occur within the strict sphere of a subject, but depend on the development of a whole curriculum and experiences that students have along their formation programs, what in the case of our institution, is covered by the curriculum reformulation recently proposed and implemented (2004) in the Medicine program. However, we believe that having a subject objectively and expressly focused on such content is an element that can make a difference in the student's formation. At least, that's what is intended. 
Within this context, the subject proposes that students know, discuss and experience in the classroom practice and/or within the social context, the Health Education approach, based on several educative strategies where they can identify and exercise their educative role as health professionals.

One of the educative strategies presented, discussed and experienced in loco, in this subject, are the game and/or group dynamics and playful activities. Strategies intended to think of and exercise the individual and the collective attitudes, evidently from the differences standpoint. Diverse-natured differences (gender, age, culture, socio-economic origin, profession, instruction and/or education level, ethnicity, thinking, etc.), as much diverse as human beings and the educative possibilities are to deal with them, and the knowledge constructions derived from there.

We considered what other experiences with games or playful activities have pointed both in the work with children (Melo, 2005), and adults, patients under treatment and health rehabilitation (Torres et al., 2003). Experiences that confirm and emphasize the potential of this type of activity for the stimulation to social life and the student's constructive process, for the problem and solution exchange and sharing opportunities, in an interactive, horizontal and dialogic manner (Freire, 2000). A perspective that has shown to be very effective in educative terms, mainly in relation to strategies intended for education and health promotion.

It is still worth emphasizing that playful activities enable teachers and students, in an educative relationship, to work, exercise and reflect upon the human being nature itself, its incompleteness, what, according to Freire (1979), is the fundamental base supporting the educative process. The man incompleteness makes him an unfinished being, who does not know in an absolute manner. "Knowledge occurs through constantly surpassing ourselves" (Freire, 1979, p.29), in exchanges and horizontal relationships established between teacher and students. Para Freire (1979, p.28), "the man should be the subject of his own education", for the understanding that "nobody educates anyone", and that education is a permanent process. Thus, it's understood that the teacher should not put himself as a superior person that teaches a group of ignorant people. He points that the teacher needs to take a modest behavior, because his knowledge is relative, and recognize that students also have a relative knowledge. Understanding that people are educated because are relationship beings, able to reflect upon reality, comprehend it and make its creation and recreation possible - that's where the true meaning of education lies.

Freire (1979, p.31) understands that "Education does not consist in an adaptation process of man to society". The man only identifies himself in his own action, whose objective is the time, historicizing him, making him the subject-history. Thus, the man relationships are reflective, consequent, transcendent and temporal, that's what makes him be himself. The education needs, however, to give opportunity so that individuals can exercise their own individuality.

And that means respecting other people in their diversity, in their incompleteness.

Working the incompleteness within the educative process, in the teachers' pedagogic practice implies dialogicity, enabling the new, the different, the students' reflection and creation process, what also involves the teacher's commitment, dealing with the unexpected, the unforeseeable, the surprising experiences of the social relations at school. And why not saying in the social relations in the health field, mainly when the professionals of this area deal along their formation and professional experience with human relations, the unfinished things, the human being in their wideness and specificity.

A depiction of such incompleteness, of surprising experiences in the educative process in health and teaching health is what we described below.

\section{Description of an educative experience: the feelings game}

The activity described in this work was developed in the first semester of 2005, within the context of an elective subject, "Health Education and Communication", offered periodically to all the institution's students, but that, for time adequacy purposes, was only developed with the Medicine students. The same one involved the participation of freshman Medicine students, 
after the three first months of classes at the college. Fourteen students participated in the activity, of which nine were boys and five girls.

The activity was developed based on the study of a provocative text on the use of games in the educative work with groups of diabetic patients (Torres et al., 2003). The proposal was for a group of students to lead the discussion on the said text in the classroom, establishing a problem and pointing their contributions to the health practice in theoretical and practical terms. Beside the text, the students were provided with an example of game (mentioned, but not developed in the text), called "Barquinhas do sentimento" ["Boats of feeling"] (Gonçalves \& Perpétuo, 2002), whose original proposal was to raise the joy and sorrow feelings among the participants in the game, working the empathy and emotional aspects in the individual and group perspective.

The Group proposed that the theme "Group's Mental Health" should be expressed in the group dynamic based on the students' positive and negative feelings in the three first months of the program. ${ }^{2}$

The group accepted the game rules and it occurred, in a first moment, through the writing of the feelings, in a very easy manner (those written records were used as a base in our analysis and reflection about this experience). After writing about the feelings, these writings were collected in a box and redistributed among the participants, who proceeded with the reading, socialization and discussion about the feelings expressed by the group. The moment of socialization of those feelings revealed positive and negative common points, frustrations and even critiques about the direction of the first year's subjects, including that that enabled the performance of this dynamics (which contrasted, from the approach standpoint, with the other essentially basic subjects of the first year's curriculum).

The approach to the theme "group's mental health" was very favorable to the feelings socialization, the sharing of common experiences and the exchange of knowledge and survival strategies when entering the university, what maybe had not occurred, at least in the group's, the collective perspective, and worked as an anchor, as a mutual support for the group. This group space was very fertile, not only for the feelings socialization, but also for critiques and suggestions on activities carried out along the course, at least during the first year, a crucial moment for any student entering the higher education.

The theme proposed personally moved and involved the group participants, maybe due to one of the group members' family life experiences and the condition of entering the university (it's worth remembering that it is about a Medicine program). Especially this latter factor seems to have been decisive in the choice of the educative action proposed by the group: the students had entered the university only three months before and experienced moments of a lot of pressure, with tests, works, need of study habits and rhythm. Finally, they were experiencing the rites of transition from the pre-university-student phase to undergraduate students of Medicine at that time, with new routines (activities, study, dwelling, sleep, etc.) and personal and/or family pressures so that they kept on succeeding in their personal and academic life. This was a situation related to the students from the group under consideration and that moved the group making them propose the theme "Group's Mental Health" as a work subject using the game mentioned. Even though it was the teacher that suggested the game exemplification, the group was quite sensitive when proposing that the game theme should be something that made sense to them and their colleagues and that could be used as a self-knowledge and learning method. The educative space provided by the activity was quite creative, productive, but at the same time unexpected, unusual, surprising: when we proposed that the group should discuss about the theme and give examples through the use of one of the games, we didn't realize that the game's subject theme could be exactly the "group's mental health". On the other hand, neither the group students themselves realized that the dynamics would take such dimension, both in the feelings expression and the anticipated and spontaneous evaluation of the subjects and the first semester of course. And it is exactly in this process to deal with the unusual; with the reflection on the reality experienced and situating yourself in the group; with the unexpected; with feelings (afflictions, frustrations, wishes, etc.); with the unfinished condition of the individuals in formation - youngs in process of change of life phase, experiencing rites of transition that

\footnotetext{
${ }^{2}$ The data generated about the "group's mental health" will be another text's subject of analysis.
} 
made them unstable, confused and insecure before the entrance to the course, the study and work burden - that lies the richness of the educative process described.

As an educator and also as an unfinished being that forms and is formed through the students' formation process (Freire, 2000), it was impossible not to get involved, not to situate only as a teacher, but as a person and professional that has as one of his/her functions at the institution, beside teaching in the graduation program, the "support, direction and assistance to students and teachers in the teaching-learning process issues", through the Núcleo de Apoio DidáticoPedagógico [Center for Didactic-Pedagogical Support] (Magalhães et al., 2006), which has worked since the curriculum restructuralization and that has been built jointly with the institution's ongoing curriculum change and restructuralization process.

Such creative experience of the students and with them allowed us not only to rethink about our work in the subject but also share it with other teachers that taught those students during that semester, its developments for the freshman students and for us, their formers, also in a continuous process of teachers' formation and learning (Mizukami et al., 2002).

\section{Looks, actions resizing...new constructions}

To conclude, we raised some questions and pointed some reflections:

by the way, what did we teach and learn with this educative experience with the students? What constructions did it cause in our teaching practice at the institution?

Casting an inquiring and reflective look about our practice and this specific experience made us and makes us deconstruct and reconstruct our behavior and practice as a former of health professionals who is also formed along with them.

The sensitive listening to this act of situating in the world, in the social reality as freshman Medicine students, as people endowed with feelings, people that experience problems, but that are also able to give ground and voice, within their own formation process, to the thinking about the health prevention and promotion process, in this case, the group of students' mental health, showed to be essential in the educative practice developed.

The students' sensitiveness arose when they took their own situation of students as a subject of analysis and reflection: a two-way educative process, through which students and the teacher could mutually teach and learn.

Our look resizing as teachers was fundamental not only about our punctual practice in the said subject, but also as educators of health professionals in formation. Such professionals need to develop and being developed within a more human and integral perspective.

Thus, this experience raised our awareness and stimulated us to explore and build new courses and possibilities to work on the mental health promotion along with institution's freshman students, the earliest as possible, in order to help them solve or at least, attenuate the traumas and wishes of the rite of transition to university life, and emotions, conflicts and frustrations faced along the Medicine program, what has been pointed as essential in the identity building process of the doctor in formation (Ramos-Cerqueira \& Lima, 2002).

Based on this experience, several activities, focused on the students' mental health, are being organized and developed in a program to welcome the institution's freshman students. A success built jointly with students and, moreover, a challenge to be overcome collectively, in the joint and dialogic work recommended by a humanized teaching practice and sought by the health formation.

Besides, our teachers' learning process itself was focused and is used as a base for our dialog and constructions with other peer teachers and workmates at the institution.

\section{Bibliographic References}

ASSIS, M. Uma nova sensibilidade nas práticas de saúde. Interface - Comunic., Saúde, Educ., v.5, n.8, p.139-40, 2001. 
BAREA L.M.; MAGALHÃES, C.R.; CASTRO, E.C.; TRINDADE, C. S.; PELLANDA, L.C. SANTOS, E.F.S.I. A formação continuada de docentes do ensino superior em saúde: desafios e perspectivas de uma experiência no próprio local de trabalho. Rev. Dig. Educ. Permanente em Saúde, v.29, n.2, supl.1, p.157-8, 2005.

BOGDAN, R.; BIKLEN, S. Investigação qualitativa em educação: uma introdução à teoria e aos métodos. Porto: Porto Editora, 1994.

FREIRE, P. Pedagogia da autonomia: saberes necessários à prática educativa. São Paulo: Paz e Terra,

2000.

Rio de

A educação e o processo de mudança social. In: Educação e mudança. 2. ed.

Janeiro: Paz e Terra, 1979. p.27-41.

GARCIA, M.A.A. Saber, agir e educar: o ensino-aprendizagem em serviços de saúde. Interface - Comunic., Saúde, Educ., v.5, n.8, p.89-100, 2001.

GONÇALVES, A.M.; PERPÉTUO, S.C. Barquinhas do sentimento. In: (Orgs.).

Dinâmica de grupos na formação de lideranças. Rio de Janeiro: DP\&A Editora, 2002. p.90-1.

LAMPERT, J.B. Tendências e mudanças na formação médica no Brasil: tipologia das escolas. São Paulo: Hucitec/Abem, 2002.

LUDKE, M.; ANDRÉ, M.E.D.A. Pesquisa em educação: abordagens qualitativas. São Paulo: EPU, 1986.

MAGALHÃES, C.R.; STENZEL, L.M.; COSTA, B.M. Núcleo de Apoio Psicopedagógico: elementos de um percurso. Rev. Bras. Educ. Méd., v.30, n.2, compl. 1, p.3, 2006.

MELO, C.M.R. As atividades lúdicas são fundamentais para subsidiar o processo de construção do conhecimento (continuação). Inf. Filos., v.2, n.1, p.128-37, 2005.

MIZUKAMI, M.G.N.; REALI, A.M.M.R.; REYES, C.R.; MARTUCCI, E.M.; LIMA, E.F.; TANCREDI, R.M.S.P.; MELLO, R.R.. Escola e aprendizagem da docência: processos de investigação e formação. São Carlos: EdUFSCar, 2002.

MIZUKAMI, M.G.N.; REALI, A.M.M.R.; REYES, C.R.; LIMA, E.F.; MARTUCCI, E.M.; ABIB, M.L.V.S.;

MELLO, R.R.; TANCREDI, R.M.S.P. A reflexão sobre a ação pedagógica como estratégia de modificação da escola pública elementar numa perspectiva de formação continuada no local de trabalho. In: ENCONTRO NACIONAL DE DIDÁTICA E PRÁTICA DE ENSINO, 9., 1998, Águas de Lindóia. Anais II... Águas de Lindóia, 1998. v.2, p.490-509.

RAMOS-CERQUEIRA, A.T.A.; LIMA, M.C.P. A formação da identidade do médico: implicações para o ensino de graduação em Medicina. Interface - Comunic., Saúde, Educ., v.6, n.11, p.107-16, 2002.

SCHÖN, D. Formar professores como profissionais reflexivos. In: NÓVOA, A. (Org.) Os professores e sua formação. Lisboa: Dom Quixote, 1993. p.77-91.

TORRES, H.C.; HORTALE, V.A.; SCHALL, V. A experiência de jogos em grupos operativos na educação em saúde para diabéticos. Cad. Saúde Pública, v.19, n.4, p.1039-47, 2003. 
VASCONCELOS, E.M. Redefinindo as práticas de saúde a partir de experiências de Educação Popular nos serviços de saúde. Interface - Comunic., Saúde, Educ., v.5, n.8, p.121-6, 2001.

ZABALZA, M.A. Diários de aula: contributo para o estudo dos dilemas práticos dos professores. Portugal: Porto Editora, 1994.

Received on 06/21/06.

Approved on 05/29/07.

Translation from Interface - Comunicação, Saúde, Educação, Botucatu, v.11, n.23, p.647-654, Sept./Dec. 2007. 